\title{
Aspectos Moleculares da Determinação e Diferenciação Sexual
}

\section{revisão}

\section{RESUMO}

Embora muitos eventos que participam do processo de desenvolvimento sexual normal não estejam elucidados, está estabelecido que a determinação do sexo gonadal é a responsável pela diferenciação sexual durante a vida fetal. Deste processo participam vários genes que interagem entre si, como SRY e DAXI, localizados nos cromossomos sexuais e os autossômicos WT-1, SF-1 e SOX9. Sua ação na determinação gonadal ainda não está esclarecida, mas mutações identificadas nestes genes resultaram na ausência da formação gonadal ou na presença de gônadas disgenéticas. A diferenciação da genitália interna masculina incluindo a descida testicular, requer secreção e ação local normal da testosterona nos ductos de Wolf e do hormônio anti mülleriano (HAM) nos ductos de Müller, impedindo sua diferenciação. Os genes Ins/3 e HOX participam da descida intra-abdominal dos testículos na espécie humana, e a descida inguino-escrotal é controlada pelos andrógenos, sendo os principais genes envolvidos nessa fase da embriogênese o do receptor de andrógenos, o do HAM e o do seu receptor. Mutações em um desses genes resultam em ambigüidade e/ou subdesenvolvimento da genitália interna masculina. No sexo feminino, os genes da familia Wnt (Wnt-7a e Wnt-4) parecem ter um papel no desenvolvimento dos ductos Müllerianos e na supressão da diferenciação das células de Leydig no ovário. A ambigüidade genital pode resultar da deficiência da produção de testosterona pelas células de Leydig, de distúrbios no receptor androgênico ou de defeito na metabolização da testosterona pela $5 \alpha$-redutase 2. Estão envolvidos nesta fase da diferenciação os seguintes genes: do receptor do LH/hCG, do CYPIlAl, do P450scc, do CYP17, do HSD3B2 e do HSD17B3 que codificam as respectivas enzimas envolvidas na síntese de testosterona, além do gene do receptor androgênico e do gene SRD5A2. Avanços na compreensão dos mecanismos envolvidos nos processos da determinação e diferenciação sexual foram possíveis com os novos conhecimentos de biologia molecular. Diversas etapas deste processo serão ainda esclarecidas com a identificação de novos genes, que também participam deste complexo mecanismo de interações gênicas. (Arq Bras Endocrinol Metab 2002;46/4:433-443)

Descritores: Determinação gonadal; Diferenciação sexual

\author{
Sorabia Domenice \\ Elaine M.F. Costa \\ Rafaela V. Corrêa \\ Berenice B. Mendonça
}

Unidade de Endocrinologia do Desenvolvimento, Laboratório de Hormônios e Genética Molecular/LIM 42, Disciplina de Endocrinologia, Hospital das Clínicas da Faculdade de Medicina da USP (FMUSP), São Paulo, SP.

\begin{abstract}
Molecular Aspects of Sexual Determination and Differentiation.

Many of the events that influence the process of normal sexual development have not been completely clarified, however it is well established that gonadal sex determination is responsible for sexual differentiation during fetal life. Several interacting genes participate in this process, and the most important are: SRY and DAX-1 genes located in the sexual chromosomes and the autosomic genes WTI, SF-1, and SOX9. The precise action of these genes on gonadal determination is yet to be clarified, but their participation is fundamental since mutations identified in these genes result in the absence of gonadal development or the
\end{abstract}

Recebido em 22/07/2002 Aceito em 30/07/2002 
presence of dysgenetic gonads. The differentiation of male internal genitalia including testicular descent, require both normal secretion and local action of testosterone on Wolffian ducts and anti-müllerian hormone gene (AMH) on Müllerian ducts, preventing their differentiation into uterus, vagina and tubes. The genes Ins/3 and HOX participate of the transabdominal descent of testes, and inguinal-scrotal descent is controlled by androgens. Nonetheless, the main genes involved in this early embryogenic phase are: the androgen receptor gene, $\mathrm{AMH}$ gene and the $\mathrm{AMH}$ receptor gene. Mutations in one of these genes result in genital ambiguity and/or partial development of male internal genitalia. In the female sex there has been recent evidence that genes from the Wnt family (Wnt-7a and Wnt-4) have a role in the development of Müllerian ducts and the suppression of Leydig cell differentiation in the ovaries. The ambiguous external genitalia result in testosterone production deficiency by Leydig cells, androgen receptor impairment, or a defect in peripheral testosterone metabolism by 5-alpha-reductase type 2 . The genes involved in this phase of male sex differentiation are: $\mathrm{LH} / \mathrm{hCG}$ receptor gene, CYPl1Al gene, P450scc gene, CYP17 gene, HSD3B2 gene and HSD17B3 gene that codify the respective enzymes involved in testosterone synthesis, along with the androgen receptor gene and SRD5A2. The new achievements of molecular biology determined a better comprehension of the process of sexual determination and differentiation. Several steps of this process will be clarified, with the identification of new genes that also participate of this complex mechanism of gene interactions. (Arq Bras Endocrinol Metab 2002;46/4:433-443)

Keywords: Gonadal determination; Sexual differentiation

\section{DETERMINAÇÃO SEXUAL}

O PROCESSO DE DESENVOLVIMENTO SEXUAL nos mamíferos se inicia no momento da fertilização com o estabelecimento do sexo cromossômico do zigoto e é determinado pela interação de genes, fatores transcricionais, hormônios e receptores hormonais.

Neste processo a determinação sexual e a diferenciação sexual ocorrem como etapas distintas e seqüenciais. $\mathrm{O}$ evento primário consiste na determinação do sexo gonadal que define o desenvolvimento da gônada embrionária indiferenciada no sentido masculino ou feminino.

A organização da crista urogenital primitiva é controlada por proteínas do grupo homeodomain (LIMl) e por fatores transcricionais como os da família dos receptores nucleares (SF-l e WTl). O pa- drão temporal e topográfico da expressão de genes como SF-1 e WTI sugerem que eles participam da preparação do tecido gonadal bipotencial para a etapa de determinação do sexo gonadal. O gene LIMl parece desempenhar um papel semelhante.

A identificação da região determinante do sexo no cromossomo Y (gene $S R$ Y) constituiu uma etapa crucial na compreensão da determinação do sexo gonadal masculino. Além do SRY, o gene SOX9 tem também um papel importante na indução da formação testicular. Outros genes localizados nos cromossomos sexuais ( $D A X I$, $A T R X)$ e em autossomos (DMRT, WNT4) também participam de etapas críticas do processo de determinação gonadal. As interações dos vários genes envolvidos no complexo mecanismo da cascata da determinação sexual estão sendo gradualmente esclarecidas. Mais recentemente, tem sido observado que a dose gênica também desempenha um papel muito importante no processo normal de formação e desenvolvimento gonadal.

$O$ processo de diferenciação sexual que se segue à definição do sexo gonadal compreende todos os eventos subseqüentes à organogênese gonadal e será abordado com detalhes em seqüência (Parte II).

\section{CLASSIFICAÇÃO DAS ANOMALIAS DA DETERMINAÇÃO SEXUAL}

São classificados como portadores de sexo reverso os pacientes nos quais o sexo genético, determinado pela presença ou ausência do cromossomo $\mathrm{Y}$, não corresponde ao sexo gonadal. Neste grupo de pacientes estão incluídos aqueles com cariótipo 46,XX e desenvolvimento de gônada masculina (homens XX e hermafroditas verdadeiros $46, \mathrm{XX}$ ) e os pacientes com cariótipo 46,XY e presença de gônadas disgenéticas ou ausência de desenvolvimento gonadal (disgenesia gonadal completa (DGC), disgenesia gonadal parcial (DGP) e síndrome da regressão testicular embrionária).

\section{INTERAÇÃO DOS GENES ENVOLVIDOS NA DETERMINAÇÃO SEXUAL}

Vários genes localizados nos cromossomos sexuais e autossomos participam dos processos de determinação sexual. Uma complexa cascata gênica é formada por uma série de genes que interagem em fases restritas ou em diferentes momentos do desenvolvimento do tecido gonadal.

Alterações nos mecanismos de ação e nas interações gênicas dão origem a diferentes graus de anor- 
malidades no desenvolvimento gonadal, que resultam na formação de gônadas disgenéticas ou em agenesia gonadal. Anormalidades na dosagem dos genes envolvidos na determinação sexual, seja por insuficiência ou por excesso de expressão gênica, são também identificadas nos portadores de sexo reverso 46,XX e 46,XY.

\section{GENES ENVOLVIDOS NA DETERMINAÇÃO GONADAL}

\section{Genes Localizados nos Cromossomos Sexuais: SRY, Locus DSS (DAX1/ NROB 1) e ATR-X}

1. Gene SRY (Gene da região determinante do sexo do cromossomo Y) - OMIM 480000. O gene SRY humano está localizado próximo à região pseudoautossomal do braço curto do cromossomo Y (Yp 11.3). É constituído por um exon único e codifica uma proteína de 204 aminoácidos. A proteína SRY possui um domínio central de ligação ao DNA denominado HMG box homólogo ao núcleo de ligação das proteínas nucleares da alta mobilidade.

A presença do cromossomo $\mathrm{Y}$ é reconhecida como o fator determinante do desenvolvimento gonadal masculino em humanos desde a década de 50, quando as técnicas de citogenética para o estudo das alterações cromossômicas começaram a ser utilizadas. A identificação do gene $S R \Upsilon$, no braço curto do cromossomo Y, no início da década de 90 , permitiu o esclarecimento de uma importante etapa no processo de determinação da gônada embrionária masculina $(2,3)$.

O gene SRY age como um indutor na determinação sexual masculina. A sua expressão nas células somáticas da crista genital precede os primeiros sinais do desenvolvimento testicular. O desenvolvimento do testículo inicia-se com a transformação dos precursores das células de suporte em células de Sertoli, as quais vão direcionar o desenvolvimento das demais células da gônada. Assim, na vizinhança das células de Sertoli os precursores das células esteróidicas desenvolvem-se em células de Leydig e as células germinativas em espermatogônias.

A confirmação do gene $S R \Upsilon$ como fator determinante testicular foi realizada através do experimento de Koopman, no qual a inserção de um fragmento de $14 \mathrm{~kb}$ de DNA contendo o gene Sry murino em ovos XX fertilizados determinou o desenvolvimento da gônada masculina (4). A natureza transitória da expressão do gene Sry na gônada masculina sugere que ele aja como um regulador de outro(s) gene(s), provavelmente um gene repressor da inibição do desenvolvimento testicular. A interação do $S R \Upsilon$ com os genes da família $S O X$, especialmente o $S O X 9$, parece ser fundamental no desenvolvimento gonadal masculino.
A ocorrência de troca de material entre os cromossomos paternos $\mathrm{X}$ e $\mathrm{Y}$ durante a meiose, com a transferência de fragmentos do cromossomo Y para o $\mathrm{X}$ foi sugerida na década de 60 como a causa de sexo reverso 46,XX. Esta hipótese foi confirmada pela demonstração da presença de seqüências específicas de $\mathrm{Y}$ no cromossomo $\mathrm{X}$ de alguns pacientes (5). A determinação gonadal masculina em indivíduos 46,XX foi creditada à transferência de um fator determinante testicular do Y para o X. A forma clássica de homem XX, que apresenta genitália masculina normal, foi relacionada à presença de $S R \Upsilon$ no genoma, enquanto os homens XX com ambigüidade genital usualmente não apresentam material de $\mathrm{Y}$ detectável (6). Nos raros casos de homem XX com genitália ambígua, nos quais identificou-se a presença de $S R \Upsilon$, demonstrou-se que este gene está localizado no cromossomo $\mathrm{X}$ inativo (7). Embora seqüências do cromossomo Y possam ser detectadas em alguns hermafroditas verdadeiros 46,XX e homens XX com ambigüidade genital, a maioria destes pacientes não apresentam seqüências do cromossomo Y, incluindo-se o gene $S R Y$, o que sugere a participação de outros genes neste processo. A descrição numa mesma família de pacientes com diagnóstico de hermafroditismo verdadeiro e homens XX sugere uma etiologia comum para estas doenças.

Na grande maioria dos pacientes com disgenesia gonadal 46,XY demonstrou-se a presença de um gene $S R \Upsilon$ normal. A freqüência de mutações descritas no gene SRY nos casos de disgenesia gonadal 46 ,XY se aproxima de $15 \%$ (8). As mutações identificadas no $S R \Upsilon$ foram localizadas principalmente na região do $H M G$ box, região esta responsável pela ligação da proteína SRY ao DNA e pela indução das modificações da configuração espacial dos sítios-alvo de ligação.

Raras mutações foram identificadas fora do $H M G$ box em pacientes com diagnóstico de DGC e DGP. A ausência de mutações no gene $S R \Upsilon$ em material gonadal de pacientes com DG 46,XY afastou a possibilidade de mutações restritas ao tecido gonadal serem a causa da doença. A maioria das mutações descritas no gene $S R \Upsilon$ são mutações de novo. Entretanto, são descritos casos de pais férteis com filhos portadores de sexo reverso $46, \mathrm{XY}$ que apresentam as mesmas seqüências alteradas do gene $S R Y$. A presença de mosaicismo no pai para a variante foi demonstrada em um caso (9). Uma penetrância incompleta da mutação do gene $S R \Upsilon$ tem sido também proposta para explicar os achados de casos familiares de homens normais e afetados portadores das mesmas seqüências mutadas do gene $(10,11)$. 
A análise das propriedades bioquímicas dos domínios de ligação ao DNA das proteínas $S R \Upsilon$ mutantes demonstraram anormalidades tanto no processo de afinidade de ligação como modificações espaciais geradas nas angulações da fita de DNA impedindo a formação do complexo DNA-proteína $S R \Upsilon$ (11).

2. Locus DSS (Dosage Sensitive Sex reversal) Gene DAXI (gene I da região critica DSS - Hipoplasia adrenal congênita do cromossomo X) / NROBI - OMIM 300200. O locus DSS está localizado na região Xp21 adjacente ao locus da hipoplasia adrenal congênita (HAC). O gene DAXl foi isolado em associação a uma ilha CpG do segmento de sobreposição da região crítica DSS e HAC (Xp21.3). Este gene codifica um novo membro da superfamília de receptores nucleares com um único domínio de ligação ao DNA. Difere dos outros membros desta família pois perdeu um domínio típico zinc-finger que participa da ligação ao DNA. É um gene constituído por 2 exons e codifica uma proteína de 470 aminoácidos.

A identificação de pacientes com sexo reverso 46,XY portadores de duplicações de porções do braço curto do cromossomo X (região Xp21.2-22.1) permitiu relacionar estes loci ao desenvolvimento gonadal. Bardoni denominou a região de $160 \mathrm{~kb}$ do cromossomo $\mathrm{X}$ (Xp21) adjacente ao locus da hipoplasia adrenal congênita de locus Dosage Sensitive Sex reversal (DSS) (12).

Deleções da região crítica DSS estão associadas a manifestações da síndrome dos genes contíguos que incluem hipoplasia adrenal congênita, hipogonadismo hipogonadotrófico, deficiência de glicerol quinase, doença de Aland Island eyes, perda auditiva, retardo mental e distrofia muscular de Duchenne. Embora estes pacientes possam apresentar hipogonadismo hipogonadotrófico e criptorquidismo, apresentam genitália interna e externa masculina normal. Mutações no gene $D A X I$ foram descritas em pacientes com diagnóstico de hipoplasia adrenal congênita ligada ao cromossomo X (13).

A expressão do gene $D A X 1$ foi demonstrada primariamente nos tecidos esteroidogênicos incluindo o córtex adrenal, testículo (células de Leydig), ovário (células da teca e granulosa, além da hipófise, do hipotálamo e da crista urogenital.

O processo normal de inativação do cromossomo X ocorre precocemente na gestação, antes da $8 \underline{\text { a a }}$ 12a semanas, período correspondente ao início da diferenciação gonadal. A presença de genes do cromossomo $\mathrm{X}$, que normalmente estão submetidos à inativação, se ativados em dose dupla poderiam estar relacionados a distúrbios do desenvolvimento gonadal em pacientes com sexo reverso.
Em indivíduos masculinos normais o desenvolvimento ovariano e a função DSS são reprimidos durante a formação testicular pela presença do gene $S R \Upsilon$. A dupla dosagem ativa do gene situado no locus DSS, em indivíduos com duplicações Xp, mesmo na presença de um gene $S R \Upsilon$ funcionalmente normal poderia determinar a perda da atividade repressora do $S R Y$ sobre um segundo gene repressor situado no locus DSS. Assim, a função deste gene do locus DSS de inibir outros genes responsáveis pelo desenvolvimento gonadal masculino não estaria mais adequadamente reprimida pelo SRY. Neste contexto, poderia ocorrer o desenvolvimento de uma gônada disgenética e um fenótipo de sexo reverso.

Em estudos com camundongos transgênicos a expressão aumentada do gene Daxl induziu o desenvolvimento de animais com sexo reverso. Este achado, sugere um possível papel do gene $D A X I$ no desenvolvimento de gônadas disgenéticas em pacientes portadores de duplicação de Xp (14). No entanto, até o momento nenhum paciente portador de DG 46,XY e excesso de expressão (duplicação) do gene $D A X I$ foi descrito.

3. Gene ATR-X ( $\alpha$-talassemia e retardo mental ligada ao X) - OMIM 300032. O gene ATRX (ou gene da helicase 2 ligado ao $\mathrm{X}-\mathrm{H} 2 \mathrm{X}$ ) está localizado no braço longo do cromossomo X (Xq13). Este gene é constituído por 35 exons e codifica uma proteína nuclear NTP de ligação homóloga a diversos membros da superfamília helicase II. A proteína ATRX pode estar envolvida na regulação da transcrição gênica via modulação da estrutura da cromatina.

A síndrome ATR-X é caracterizada por retardo mental severo, $\alpha$-talassemia e múltiplas anomalias congênitas incluindo anormalidades genitais. A descrição de pacientes portadores da síndrome e disgenesia gonadal 46,XY relacionam o gene ATR $X$ ao desenvolvimento testicular humano $(15,16)$.

\section{Genes Localizados nos Autossomos: SF-1 (NR5A1), WT1, SOX9, WNT4, DMRT1 e DMRT2}

1. Gene SF-1 (Gene do Fator Esteroidogênico 1)/ NR5AI OMIM - 184757. O gene SF-1 humano está localizado no braço longo do cromossomo 9 (9q34). Este gene é constituído por 7 exons, incluindo o primeiro exon não traduzido, e codifica uma proteína constituída por 461 aminoácidos. Este gene é um membro da família dos receptores nucleares.

O gene $S F-1$ foi primeiramente identificado como um ativador de genes envolvidos na biossíntese dos esteróides. Ele age como um regulador da função endócrina no eixo hipotálamo-hipófise-gonadal e no córtex adrenal, sendo um fator essencial na determi- 
nação e diferenciação sexual (17). A expressão do SFl é necessária em três momentos durante o desenvolvimento testicular: na gônada bipotencial antes da determinação testicular, nas células de Sertoli regulando a expressão do gene do hormônio anti-mülleriano (HAM) e nas células de Leydig regulando a produção dos hormônios esteróides.

Estudos de expressão gênica em camundongos mostraram que o $S f l$ está expresso na crista urogenital de embriões de camundongos nos estágios mais precoces da organogênese das gônadas. Camundongos femininos ou masculinos com bloqueio da atividade do gene SfI apresentam genitália interna e externa feminina e morrem no período neonatal por insuficiência adrenal. Estes animais apresentam ausência do desenvolvimento gonadal e adrenal e alterações na atividade dos gonadotrófos (17).

Quatro mutações no gene SF-1, que determinam insuficiência de sua expressão, foram descritas em humanos. Todos os pacientes 46,XY eram portadores de disgenesia gonadal. Apenas um paciente 46,XY apresenta comprometimento gonadal isolado sem insuficiência da glândula supra-renal $(18,19)$.

2. Gene WTI (Gene supressor do tumor de Wilm's) - OMIM 194070. O gene WTI em humanos está localizado no braço curto do cromossomo 11 (11pl3) e é constituído por 10 exons incluindo dois sítios de splicing alternativos nos exons 5 e 7 . A presença de sítios alternativos de splicing e de início de tradução gera diversas isoformas da proteína WTl. Um balanço preciso entre as diversas isoformas do WTl parece ser necessário para uma função normal da proteína.

O gene WTI é expresso muito precocemente durante o desenvolvimento da crista urogenital e tem sido implicado no desenvolvimento renal e gonadal precoce. Em camundongos, a perda em homozigose do gene WtI determina a ausência de desenvolvimento renal e gonadal. Como resultado da degeneração gonadal precoce a genitália interna e externa destes animais desenvolve-se no sentido feminino.

As mutações identificadas no gene WTl em humanos são usualmente em heterozigose. Mutações neste gene, que determinam insuficiência de expressão (haploinsuficiência) estão envolvidas em três diferentes síndromes relacionadas entre si. Deleções em heterozigose do gene são associadas com malformações genitourinárias leves, predisposição para o desenvolvimento de tumores renais na infância além de aniridia $\mathrm{e}$ retardo mental na síndrome de WAGR (20). Na síndrome de Denys-Drash mutações em heterozigose no domínio de ligação ao DNA do gene WTI levam a severas e freqüentes malformações urogenitais. Tumor de Wilm's na primeira década de vida e insuficiência renal (esclerose mesangial difusa) de início precoce são manifestações da síndrome associadas a pseudohermafroditismo masculino. Indivíduos 46,XY com a síndrome de Denys-Drash mostram genitália ambígua ou feminina confirmando o envolvimento deste gene no desenvolvimento gonadal masculino (21). Na síndrome de Frasier os pacientes 46,XY apresentam genitália externa feminina normal, gônadas em fita e desenvolvem uma glomerulopatia progressiva. Estes pacientes apresentam alto risco de desenvolverem gonadoblastoma nas gônadas disgenéticas. Nestes pacientes foram descritas mutações em heterozigose, quase todas localizadas no intron 9, que determinam mudança no sítio doador de splice do WTI resultando em inversão na razão das isoformas da proteína WTl com predomínio da isoforma longa sobre a isoforma curta. Esta alteração na razão das isoformas interfere no funcionamento normal da proteína WTl e leva ao desenvolvimento da síndrome $(22,23)$.

3. Gene SOX9 (SRY-related HMG-box gene 9) OMIM - 114290. O gene SOX9 é um fator transcricional, membro da família dos genes SOX que contém um núcleo $H M G$ box semelhante ao do gene SRY. Em humanos o gene SOX9 está localizado no braço longo do cromossomo 17 (17q24) e é constituído por três exons codificando uma proteína com 509 aminoácidos.

Este gene é expresso nos testículos em desenvolvimento e em condensações mesenquimais precursoras de cartilagens e ossos. Estudos da expressão do gene $\operatorname{Sox} 9$ em camundongos demonstraram que o gene está expresso em baixos níveis nos primórdios gonadais femininos e masculinos e sua expressão persiste nas células de Sertoli, desaparecendo no tecido ovariano. Dados experimentais sugerem que o gene $S O X 9$ é um gene determinante testicular e que está sujeito à regulação de diferentes genes entre os quais o gene $S R \Upsilon$ e o gene $D A X I$ (locus DSS) (24).

Mutações em heterozigose no gene $S O X 9$, que determinam haploinsuficiência do gene, estão relacionadas ao desenvolvimento da síndrome da displasia campomélica. Nesta síndrome constituída por malformações esqueléticas múltiplas observa-se um aumento na prevalência de disgenesia gonadal em pacientes $46, \mathrm{XY}$ e sexo reverso. Recentemente, um caso de sexo reverso 46,XX associado à duplicação da região genômica contendo o gene $S O X 9$ foi descrito sugerindo que a expressão aumentada do gene poderia determinar o desenvolvimento da gônada masculina na ausência do gene $S R Y(25)$. 
4. Gene WNT4 (Wingless-type mouse mammary tumor virus integration site member 4) OMIM 603490. O gene WNT4 é membro da grande família de WNT genes que codificam glicoproteínas sinalizadoras extracelulares. O gene WNT4 humano está localizado no braço curto do cromossomo l (1p31p35) e é constituído por 5 exons que codificam uma proteína de 193 aminoácidos.

O gene Wnt4 é expresso precocemente no mesonefron em desenvolvimento e também está envolvido no desenvolvimento gonadal. Sua expressão é diminuída no testículo porém permanece no ovário. Modelos de animais mutantes knockout para o gene Wnt4 demonstram o seu papel no desenvolvimento feminino, indicando que este gene é necessário para o desenvolvimento do ovário e dos ductos de Müller. A inativação deste gene em fêmeas de camundongos determinou a diferenciação de células intersticiais do ovário em células Leydigsímile. Estas células apresentavam a capacidade de produzir andrógenos que induziram o desenvolvimento dos ductos de Wolff e regressão dos ductos de Müller nestes animais (26).

Num paciente portador de disgenesia gonadal 46,XY com múltiplas malformações, foi identificada a

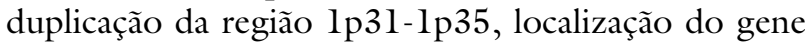
WNT4 (27). Este relato sugere a participação do gene na cascata da determinação gonadal em humanos (28). O excesso de expressão do gene WNT4 poderia determinar um efeito anti-testicular semelhante ao descrito para o locus DSS. O mecanismo proposto para a indução de sexo reverso neste caso foi um provável excesso de expressão do gene DAXI (locus DSS) secundário ao excesso de dose do WNT4.

5. Genes DMRT1 e DMRT2 (Doublesex and Mab-3 Related Transcription Factor 1 and 2) $O M I M$ - 602424. Os genes DMRT1 e DMRT2 mapeados na região do braço curto do cromossomo 9 (9p24.3) codificam proteínas que contém o núcleo de ligação ao DNA denominado DM (relativo aos genes $d s x \mathrm{e}$ mab-3 relacionados ao controle do desenvolvimento sexual respectivamente em C. elegans e em $D$. melanogaster).

A presença de sexo reverso em indivíduos 46,XY é descrita em associação com deleções 9p. Esta síndrome dos genes contíguos do $9 \mathrm{p}$ é caracterizada por graus variados de sexo reverso 46, XY, retardo mental e anormalidades craniofaciais. Entretanto, pequenas deleções poderiam estar associadas com anormalidades gonadais isoladas. Genes evolutivamente conservados com um domínio DM e relacionados ao desenvolvimento gonadal foram identifi- cados nesta região, e denominados $D M R T$. O estudo da região codificadora do gene $D M R T 1$ e no domínio DM do gene DMRT2 em pacientes com sexo reverso $46, \mathrm{XY}$ porém, não identificou mutações nestes pacientes. $\mathrm{O}$ mecanismo de haploinsuficiência para a região 9p é sugerido como causa desta síndrome (29).

\section{DIFERENCIAÇÃO SEXUAL}

A diferenciação sexual em mamíferos envolve uma cascata de genes que atuam desde a diferenciação da gônada bipotencial em testículo ou ovário (determinação sexual) até a diferenciação dos genitais internos e externos também bipotenciais em masculinos ou femininos nas primeiras semanas de vida intrauterina. A diferenciação das genitálias externa e interna no sexo masculino é um processo dependente da produção de hormônios sexuais pelo testículo, enquanto que no sexo feminino esse processo independe dos hormônios ovarianos. Portanto a diferenciação sexual é gônadadependente apenas nos homens.

O desenvolvimento do fenótipo masculino (incluindo descida testicular até a bolsa escrotal) requer a produção normal de três hormônios testiculares: HAM (hormônio anti-mülleriano), andrógenos e Insl3. Por outro lado, no sexo feminino, a ausência da produção desses hormônios determina a diferenciação sexual feminina.

Neste complexo processo de diferenciação sexual estão envolvidas numerosas enzimas, hormônios e seus receptores e fatores de transcrição. Defeitos nos genes que codificam a síntese de quaisquer destas substâncias determinam o aparecimento das anomalias da diferenciação sexual.

\section{Genes Envolvidos no Desenvolvimento dos Genitais Internos}

Os ductos mesonéfricos ou ductos de Wolff estão presentes no feto a partir da terceira semana de gestação e os ductos paramesonéfricos ou ductos de Müller aparecem a partir da sexta semana de gestação.

No feto feminino, os ductos de Müller se diferenciam em trompas e útero. A porção superior da vagina é formada pelos ductos de Müller e também de Wolff, pois na ausência dos ductos de Wolff ocorre atresia ou agenesia de vagina. Embora não haja nenhum gene específico responsável pela diferenciação dos genitais internos femininos, atualmente há evidências de que genes da família Wnt tenham um papel no desenvolvimento dos ductos Müllerianos. O Wnt-4 é 
responsável pela supressão da diferenciação das células de Leydig no ovário e o Wnt-7a é necessário para o completo desenvolvimento dos derivados müllerianos em ratas fêmeas (30). No entanto, em humanos, o papel preciso desses genes na diferenciação sexual feminina ainda não está estabelecido.

No feto masculino, através da ação local da testosterona secretada pelas células de Leydig a partir da oitava semana de gestação, os ductos de Wolff se diferenciam em epidídimo, ducto deferente e vesícula seminal e os ductos de Müller sofrem atrofia sob ação do hormônio anti-mülleriano (HAM), secretado pelas células de Sertoli.

Síntese e ação do HAM: HAM é um hormônio glicoprotéico que pertence à superfamília do TGF $\beta$ (fator transformador de crescimento- $\beta$ ) e é expresso nas células de Sertoli fetais e pré-puberais (31). O gene que codifica a sua produção contém 5 exons e está localizado no cromossomo 19 na posição 19 pl3.3-13.2 (32). A região promotora do gene do HAM apresenta sítios de ligação para SF-1 e Sox9 além de um sítio GATA (31), portanto o Sox9 pode ligar-se à região promotora desse gene e interagir com o SF-1 que ativa a transcrição do gene do HAM. Embora o WT-1 não seja capaz de ligar-se à região promotora do gene do HAM, ele interage fisicamente com o SF-1 ativando a transcrição desse gene (33). Portanto, a transcrição do gene do HAM, na vida intrauterina, é regulada por outros fatores implicados na diferenciação sexual incluindo o SF-1, Sox9, GATA-4 e WT-1.

O HAM é produzido pelas células de Sertoli não só na fase embriogênica (entre a $9^{\mathrm{a}}$ e a $1 \mathrm{l}^{\mathrm{a}}$ semanas de gestação), mas também no final da gestação, após o nascimento e ainda no adulto, porém em níveis bem mais baixos, sugerindo que esse hormônio tem uma ação funcional no testículo maduro, além da sua ação na regressão dos ductos de Müller e na descida testicular no final da gestação. Recentemente, Teixeira e col. mostraram dados que indicam que o HAM regula a síntese de andrógenos suprimindo diretamente a transcrição do gene $\mathrm{P} 450 \mathrm{cl} 7$ que codifica a produção das enzimas $17 \alpha$ hidroxilase e 17,20 desmolase envolvidas na síntese da testosterona (34). A ação desse hormônio é mediada por seus receptores de membrana treonina/serina quinase tipo I e tipo II, apenas o receptor tipo II é expresso nas células mesenquimais que circundam os ductos de Müller durante o período de regressão, mas para ocorrer a sinalização pós-receptor é necessária a fosforilação do receptor tipo I. O gene que codifica o receptor tipo II do HAM contém 11 exons e está localizado no cromossomo 12 na posição $12 q 13$. A regulação de sua expressão ainda não está esclarecida.

Mutações inativadoras do gene do HAM ou do gene do receptor do HAM tipo II determinam a persistência dos ductos de Müller em indivíduos 46,XY com genitália externa masculina normal associada ou não à criptorquidia.

Para que ocorra a diferenciação dos ductos de Wolff em epidídimo, ducto deferente e vesícula seminal, é necessária produção normal de testosterona, a qual requer o envolvimento dos vários genes que codificam a sua síntese e ação nos tecidos periféricos. Essa cascata de genes será descrita a seguir.

\section{Genes envolvidos no desenvolvimento dos genitais externos}

Os genitais externos, assim como as gônadas também se desenvolvem de precursores comuns: o tubérculo genital, as pregas urogenitais, pregas lábio-escrotais e o seio urogenital.

No homem, a testosterona secretada pelos testículos é transformada perifericamente em dihidrotestosterona (DHT) através da enzima $5 \alpha$-redutase. A dihidrotestosterona age sobre os genitais externos indiferenciados, promovendo sua diferenciação em genitais externos masculinos.

Sob a ação da dihidrotestosterona, o tubérculo genital se diferencia em glande do pênis, as pregas urogenitais em corpo do pênis, as pregas lábio-escrotais em bolsa escrotal e o seio urogenital em próstata.

Na mulher, aparentemente sem ação hormonal conhecida, e mesmo na ausência de ovários, o tubérculo genital se diferencia em clitóris, as pregas genitais em pequenos lábios, as pregas lábio-escrotais em grandes lábios e o seio urogenital na porção inferior da vagina.

Controle da esteroidogênese testicular fetal: é mediada inicialmente pelo hCG e posteriormente pelo $\mathrm{LH}$, que agem através de um receptor comum, o receptor do LH/CG, pertencente à família dos receptores acoplados à proteína $\mathrm{G}$. $\mathrm{O}$ gene do receptor do $\mathrm{LH} /$ CG está localizado no cromossomo 2 na posição 2 p21. Mutações inativadoras nesse gene causam resistência testicular ao LH que resulta em pseudohermafroditismo masculino com genitália completamente feminina ou ambígua ou ainda em micropênis isolado ou associado à hipospádia em indivíduos 46,XY e resistência ovariana ao LH que resulta em infertilidade e irregularidade menstrual em pacientes 46,XX $(35,36)$.

Biossíntese da testosterona: a primeira etapa da esteroidogênese adrenal e gonadal caracteriza-se pela transferência do colesterol de fora para dentro 
da membrana mitocondrial e é mediada pela proteína, StAR (steroidogenic acute regulatory protein) que é codificada pelo gene CYPIIAl ou gene STAR localizado no cromossomo 8 no locus $8 \mathrm{pll}$.2. A região promotora desse gene contém sítios de ligação para o SF-1 e para o receptor de estrógeno, mostrando que esses produtos são importantes fatores de transcrição na regulação da expressão do gene StAR; está expresso nos ovários, testículos, córtex adrenal e rins (37). Mutações inativadoras desse gene causam hiperplasia adrenal lipoídica, que é a mais rara e mais severa forma de hiperplasia adrenal, pois nem as gônadas nem as adrenais são capazes de realizar a esteroidogênese (38).

Dentro da mitocôndria, a metabolização do colesterol em pregnenolona envolve três reações distintas: 20a-hidroxilação, 22-hidroxilação e quebra da cadeia lateral do colesterol que são mediadas pela enzima citocromo P450scc (side chain cleavage), localizada dentro da membrana mitocondrial. Essa enzima é codificada pelo gene CYP11A localizado na região q23-24 do cromossomo 15 . O gene CYPllA é expresso no córtex adrenal, células da granulosa, células de Leydig e placenta. Até o momento foi encontrada uma única mutação em heterozigose no gene CYP11A, determinando um quadro clínico severo de hiperplasia adrenal lipoídica, porém com manifestação tardia (39).

A pregnenolona formada deixa a mitocôndria e é desidrogenada na posição $3-\beta$ pela enzima $3 \beta$ hidroxiesteróide dehidrogenase. Além da pregnenolona, essa enzima regula a conversão de todos os outros $\Delta^{5}$ - $3 \beta$-hidroxiesteróides (17-OH pregnenolona, dehidroepiandrosterona e androstenediol) nos correspondentes $\Delta^{4}-3 \beta$-cetoesteróides (progesterona, 17- $\mathrm{OH}$ progesterona, androstenediona e testosterona). O gene $\mathbf{3} \boldsymbol{\beta}$-HSD codifica a síntese de duas isoenzimas $3 \beta$-hidroxiesteróide dehidrogenase (tipo 1 e tipo 2). Esse gene está localizado no cromossomo 1 no locus pll-13 e é constituído por 4 exons. Mutações inativadoras na isoenzima tipo 2 causam, nos pacientes afetados, hiperplasia adrenal congênita sob as formas perdedora (mutações do tipo nonsense) ou não perdedora de sal (mutações do tipo missense).

A pregnenolona e a progesterona são hidroxiladas na posição 17-alfa por outra enzima P450 específica $(\mathrm{P} 450 \mathrm{cl}$ ) localizada no retículo endoplasmático, formando a 17-hidroxipregnenolona e a 17hidroxiprogesterona, respectivamente. Esta mesma enzima tem como atividade adicional clivar a ponte de carbono 17,20, convertendo a 17-hidroxipreg- nenolona em dehidroepiandrosterona e a 17-hidroxiprogesterona em androstenediona (40). O gene CYP17 é constituído por 8 exons, está localizado no cromossomo 10 na posição $10 q 24.3$ e é expresso em adrenais, testículos e células da teca. Teoricamente diferentes mutações no gene CYPl7 podem resultar em deficiência da $17 \alpha$-hidroxilase ou deficiência da 17,20-liase, ou ambas. Porém, estudos in vitro da expressão da proteína de genes mutantes de indivíduos com diagnóstico clínico de deficiência isolada da $17 \alpha$-hidroxilase revelaram que ocorreu a deficiência combinada das duas enzimas em todos os casos estudados (40). A análise in vitro das enzimas mutantes $\mathrm{P} 45017 \alpha$ revela que a manutenção de $20 \%$ da atividade normal da 17,20-liase é suficiente para algum grau de masculinização.

A 17-ceto-redutase, uma enzima do retículo endosplasmático que não é um citocromo $\mathrm{P} 450$, reduz a dehidroepiandrosterona em androstenediol e a androstenediona em testosterona, que pode ser convertida em estrógeno pela ação do $\mathrm{P} 450$ aromatase, outra enzima encontrada no retículo endoplasmático. Existem 5 isoformas dessa enzima sendo que cada uma é codificada por um gene específico, todavia apenas a isoforma tipo 3 está envolvida na diferenciação da genitália em humanos. A isoenzima 17 $\beta$ HSD3 é codificada pelo gene HSD17B3 localizado no cromossomo 9 na posição $9 \mathrm{q} 22$ que é expresso primariamente nos testículos onde faz a redução de androstenediona para testosterona. Mutações no gene HSD17B3 determinam deficiente produção de testosterona e, conseqüentemente, incompleta virilização da genitália externa. Várias mutações já foram identificadas nesse gene em aproximadamente 20 indivíduos com essa deficiência e quando expressas em cultura de células in vitro, as enzimas mutantes mostram ausência de atividade. Ainda não foram relatadas mutações nos genes que codificam as outras isoformas.

Metabolização e ação da testosterona: a conversão de testosterona em dihidrotestosterona é realizada pela $5 \alpha$-redutase nos tecidos periféricos como a pele e folículos pilosos. Existem duas isoenzimas da $5 \alpha$-redutase (tipo 1 e tipo 2 ) codificadas por genes diferentes, no entanto apenas a isoforma tipo 2 está relacionada com a diferenciação da genitália externa. A $5 \alpha$-redutase tipo 2, é codificada pelo gene SRD5A2 localizado no cromossomo 2 na posição 2 p23 e constituído por 5 exons. A isoenzima tipo 2 é expressa no fígado e tecidos-alvo dos andrógenos, incluindo a genitália externa e próstata, porém não é expressa nos ductos de Wolff na época da sua diferenciação, o que suporta a idéia de que a testosterona é mais importante 
que o DHT nesse processo. Sua expressão é regulada pelos andrógenos, pois os níveis de mRNA estão elevados na próstata de animais castrados, após administração de testosterona.

Uma grande variedade de mutações já foi descrita no gene que codifica a $5 \alpha$-redutase tipo $2 \mathrm{em}$ diferentes grupos étnicos, de completa deleção do gene SRD5A2 até mutações de ponto. Vários pacientes afetados eram heterozigotos compostos para diferentes mutações. A expressão in vitro demonstra que deleções, terminação prematura de codons e defeitos no splicing determinam enzimas com diminuição da função; por outro lado, substituições de aminoácidos impedem a ligação com a testosterona ou produzem uma enzima instável. A isoenzima tipo 1 é normal em indivíduos com PHM por deficiência da $5 \alpha$-redutase, fato que pode explicar parcialmente a intensa virilização na puberdade (4l).

A ação androgênica da testosterona e da dihidrotestosterona se faz através de um único receptor citoplasmático, o receptor androgênico (RA) que contém três domínios funcionais, comuns a outros receptores nucleares: o domínio $\mathrm{N}$-terminal que é o menos conservado e está envolvido na transativação do gene, contém uma região polimórfica de glutamina devido a um número variável de repetições $C A G$ que afetam a eficiência transcricional do receptor (42). O domínio central de ligação com o DNA é a região mais conservada e o domínio C-terminal contém uma segunda região com função de ativação e é mediadora da interação das proteínas co-reguladoras, dimerização, sinalização de localização nuclear e sítio de ligação do gene.

$\mathrm{O}$ gene do receptor androgênico está localizado no cromossomo X na região Xql 1-q12. A presença de mutações nesse gene determina a síndrome de insensibilidade aos andrógenos em indivíduos XY com determinação testicular e biossíntese de testosterona normais. Numerosas mutações foram descritas nesse gene e estão detalhadas no site http//www.mcgill.ca /androgendb/. O fenótipo desses pacientes é muito variável; vai desde o totalmente feminino (CAIS), passa por vários graus de genitália ambígua até genitália externa masculina normal (PAIS).

A não identificação de mutações no gene do receptor androgênico em pacientes com quadro clínico e hormonal de CAIS ou PAIS evidencia que defeitos nas proteínas co-reguladoras podem estar relacionados com o quadro de insensibilidade androgênica nesses pacientes, porém raros estudos foram publicados até o momento $(43,44)$. Outra causa possível é a variação no número de repetições CAG no gene do RA. Repetições longas dentro da variação normal são associadas com vários graus de masculinização incompleta de causa desconhecida (45).

Vários genes envolvidos na biossíntese e ação androgênica são polimórficos, porém a relação dessas variantes gênicas com a síntese e ação dos andrógenos durante as fases precoces da diferenciação sexual ainda não está esclarecida.

\section{Genes envolvidos na migração testicular}

A migração testicular do pólo inferior do rim até a bolsa escrotal ocorre em duas fases distintas: a migração transabdominal e a descida inguino-escrotal. A fixação do testículo na parede abdominal se faz cranialmente pelo ligamento suspensório e caudalmente pelo gubernáculo. No sexo masculino o fator promotor da descida abdominal do testículo é a contração e o crescimento do gubernáculo associados à regressão do ligamento suspensório. Os fatores genéticos e hormonais envolvidos no processo de descida transabdominal ainda não estão esclarecidos em seres humanos, contudo, estudos em ratos indicam que a presença do testículo é necessária para o crescimento do gubernáculo, já outros fatores de crescimento como HAM, inibina e andrógenos não são indispensáveis para a migração testicular nesses animais.

O gene Ins13 (insulin-like factor 3 ou relaxinlike factor) é um membro da super família dos hormônios inulin-like e é especificamente expresso na célula de Leydig fetal e adulta e nas células da teca no ovário pós-natal. Está localizado no cromossomo $19 \mathrm{e}$ é constituído por 2 exons. O envolvimento desse gene na migração transabdominal dos testículos foi sugerido por alguns autores após a identificação de criptorquidia bilateral em ratos machos homozigotos para deleção pontual do gene, o gubernáculo mantém-se afilado como nas fêmeas; quando a mutação ocorre em heterozigose o grau de criptorquidia é variável ou unilateral ao nascimento e a posição testicular normalizase na vida adulta $(46,47)$. A relação desse gene na migração transabdominal dos testículos em humanos não é tão evidente, pois recentes estudos em meninos com criptorquidia bilateral mostram que mutações no gene Insl3 são raras nesses casos (48).

Outra família de genes que podem estar envolvidos na etiopatogenia da criptorquidia é a dos genes Hox, cujas mutações determinariam a perda da capacidade do gubernáculo em traduzir ou implantar a sinalização do Insl3 talvez pela perda da indução do receptor, levando a um subdesenvolvimento do gubernáculo (49).

A fase final de descida testicular, a descida inguino-escrotal, é controlada pelos andrógenos. O 
gubernáculo é rico em receptores androgênicos e a ausência dessa fase final de descida testicular nos indivíduos hipogonádicos e em pacientes com insensibilidade androgênica corrobora com essa afirmação (50).

\section{Gene envolvidos na identificação sexual}

Em humanos, a época e os fatores que influem na identificação do indivíduo com o seu sexo ainda são pouco conhecidos. Nas espécies inferiores, como o camundongo, o comportamento sexual adotado na maturidade é determinado pela ação dos hormônios sexuais na fase precoce da vida pós-natal. Em humanos, estudando indivíduos $46, \mathrm{XY}$ com mutações nos gene que codificam a $17 \beta$ hidroxiesteróide desidrogenase 3 e a $5 \alpha$-redutase 2 , observou-se que esses pacientes apresentam fenótipo feminino ao nascimento, são criados como meninas e, na puberdade, apresentam identificação com o sexo masculino e mudam o seu sexo de criação. Por outro lado pacientes $46, \mathrm{XY}$ com mutações no gene do receptor androgênico que determinam a forma completa de insensibilidade aos andrógenos também apresentam fenótipo feminino ao nascimento, são criados como meninas mas mantêm o sexo social feminino após a puberdade. Esses fatos sugerem que a ação androgênica tem uma importante influência na identificação do sexo masculino, mas a identificação de pacientes com deficiência da $5 \alpha$-redutase 2 e da $17 \beta$-hidroxiesteóide desidrogenase 3 que não mudaram para o sexo masculino na puberdade indica que fatores ambientais, sociais e psicológicos durante os primeiros anos de vida exercem importante influência na subseqüente identidade sexual (51).

\section{REFERÊNCIAS}

1. Veitia RA, Salas-Cortés L, Ottolenghi C, Pailhoux E, Cotinot C, Fellous M. Testis determination in mammals: more questions than answers. Mol Cel Endocrinol 2001;179:3-16.

2. Sinclair $A H$, Berta $P$, Palmer MS, Hawkins JR, Griffiths $B L$, Smith MJ, et al: A gene from the human sex-determining region encodes a protein with homology to a conserved DNA-binding motif. Nature 1990;346:240-6.

3. Berta P, Hawkins JR, Sinclair AH, Taylor A, Griffith BL, Goodfellow P, et al. Genetics evidence equaling SRY and the testis determining factor. Nature 1990;348:448-50.

4. Koopman P, Gubbay J, Vivian N, Goodfellow P, Lovell BR. Male development of chromosomally female mice transgenic for SRY. Nature 1991;351:117-21.

5. Fechner PY, Marcantonio SM, Jaswaney $V$, Stetten $G$, Goodfelow PN, Migeon CJ, et al. The role of the SexDetermining Region Y Gene in the etiology of 46,XX maleness. J Clin Endocrinol Metab 1993;76:690-5.

6. Boucekkine C, Toublanc JE, Abbas N, Chaabouni S, Ouahid S, Semrouni $M$, et al. Clinical and anatomical spectrum in $X X$ sex reversed patients. Relationship to the presence of $Y$ specific DNA-sequences. Clin Endocrinology 1994;40:733-42.

7. Kusz K, Kotecki M, Wojda A, Szarras-Czapnik M, LatosBielenska A, Warenik-Szymankiewics A, et al. Incomplete masculinization of XX subjects carrying the SRY gene on an inactive X chromosome. J Med Genet 1999;36:452-6.

8. Hawkins JR, Taylor A, Berta P, Levilliers J, Van der Auwera B, Goodfellow PN. Mutational analysis of SRY: nonsense and missense mutations in $X Y$ sex reversal. Hum Genet 1992;88:471-4.

9. Schmitt-Ney M, Thiele H, Kaltwasser P, Bardoni B, Cisternino $M$, Scherer $G$. Two novel SRY missense mutations reducing DNA binding identified in XY females and their mosaic fathers. Am J Hum Genet 1995;56:862-9.

10. Vilain E, McElreavey K, Jaubert F, Raymond JP, Richaud $\mathrm{F}$, Fellous M. Familial case with sequence variant in the testis-determining region associated with two sex phenotypes. Am J Hum Genet 1992;50:1008-1 1.

11. Harley VR, Jackson DI, Hextall PJ, Hawkins JR, Berkovitz GD, Sockanathan S, et al. DNA binding activity of recombinant SRY from normal males and $X Y$ females. Science 1992;255:453-6

12. Bardoni B, Zanaria E, Guioli S, Floridia G, Worley KC, Tonini $G$, et al. A dosage sensitive locus at chromosome Xp21 is involved in male to female sex reversal. Nat Genet 1994;7:497-501

13. Phelan JK, McCabe ERB. Mutations in NROBI (DAX1) and NR5A1 (SF1) responsible for adrenal hypoplasia congenita. Hum Mutation 2001;18:472-87.

14. Swain A, Narvaez V, Birgoyne P, Camerino G, LovellBadge R. Daxl antagonizes Sry action in mammalian sex determination. Nature 1998;391:761-7.

15. Gibbons RJ, Brueton L, Buckle VJ, Burn J, Clayton-Smith $\mathrm{J}$, Davison BC, et al. Clinical and hematologic aspects of the X-linked alpha-thalassemia/mental retardation syndrome (ATR-X). Am J Med Genet 1995;55:288-99.

16. Gibbons RJ, Higgs DR. Molecular-clinical spectrum of the ATR-X syndrome. Am J Med Genet 2000;97:204-12.

17. Luo X, Ikeda Y, Parker KL. A cell-specific nuclear receptor is essential for adrenal and gonadal development and sexual differentiation. Cell 1994;77:481-90.

18. Achermann JC, Ozisik $G$, Ito $M$, Orun UA, Harmanci $K$, Gurakan B, et al. Gonadal determination and adrenal development are regulated by the orphan nuclear receptor steroidogenic factor-1, in a dose-dependent manner. J Clin Endocrinol Metab 2002;87:1829-33.

19. Correa RV, Domenice S, Billerbeck AEC, Melo Karla FAS, Costa EMF, Latronico AC, et al. A microdeletion in the ligand-binding domain of steroidogenic factor 1 causing $X Y$ sex reversal without adrenal insufficiency. Pediatr Res 2001;49:55A.

20. van Heyningen $V$, Bickmore WA, Seawright A, Fletcher JM, Maule J, Fekete $G$, et al. Role for the Wilm's tumor gene in genital development? Proc Natl Acad Sci USA 1990;87:5383-6.

21. Pelletier J, Bruening W, Kashtan CE, Mauer SM, Manivel JC, Striegel JE, et al. Germline mutations in the Wilms' tumor suppressor gene are associated with abnormal urogenital development in Denys-Drash syndrome. Cell $1991 ; 67: 437-47$.

Arq Bras Endocrinol Metab vol 46 n 4 Agosto 2002 
22. Koziell A, Charmandari E, Hindmarsh PC, Rees L, Scambler P, Brook CG. Frasier syndrome, part of the Denys Drash continuum or simply a WTI gene associated disorder of intersex and nephropathy? Clin Endocrinol (Oxf) 2000;52:519-24.

23. Barbaux S, Niaudet P, Gubler MC, Grunfeld JP, Jaubert F, Kuttenn F, et al. Donor splice-site mutations in WT1 are responsible for Frasier syndrome. Nat Genet 1997; 17: 467-70.

24. Mansour S, Hall CM, Pembrey ME, Young ID. A clinical and genetic study of campomelic dysplasia. J Med Genet 1995;32:415-20.

25. Huang B, Wang S, Ning Y, Lamb NA, Bartley J. Autosomal XX sex reversal caused by duplication of SOX9. Am J Med Genet 1999:87:349-53.

26. Vainio S, Heikkila M, Kispert A, Chin N, McMahon AP. Female development in mammals is regulated by Wnt4 signaling. Nature 1999;397:405-9.

27. Elejade BR, Opitz JM, Elejade MM, Gilbert EF, Abellera M, Meisner L. Tandem Dup (1p) within the short arm of chromosome 1 in a child with ambiguous genitalia and multiple congenital anomalies. Am J Med Genet 1984; 17:723-30.

28. Jordan BK, Mohammed M, Ching ST, Delot E, Chen XN Dewing $P$, et al. Up-regulation of WNT-4 signaling and dosage-sensitive sex reversal in humans. Am J Hum Genet 2001;68:1102-9.

29. Muroya K, Okuyama T, Goishi K, Ogiso Y, Fukuda S, Kameyama J, et al. Sex-determining gene(s) on distal 9p: clinical and molecular studies in six cases. J Clin Endocrinol Metab 2000;85:3094-100.

30. Miller C, Sassoon DA. Wnt-7a maintains appropriate uterine patterning during the development of the mouse female reproductive tract. Development $1998 ; 125: 3201-11$.

31. Lane AH, Donahoe PK. New insights into Müllerian inhibiting substance and its mechanism of action. J Endocrinol 1998; 158:1-6.

32. Cate RL, Mattaliano RJ, Hession C, et al. Isolation of the bovine and human genes for müllerian inhibiting substance and expression of the human gene in animal cells. Cell 1986;45:685.

33. Nachtigal MW, Hirokawa $Y$, Enyeart-VanHouten DL, et al. Wilms' tumor 1 and Dax-1 modulate the orphan nuclear receptor SF-1 in sex-specific gene expression. Cell 1998:93:445-54.

34. Teixeira J, Fynn-Thompson E, Payne AH, et al. Müllerianinhibiting substance regulates androgen synthesis at the transcriptional level. Endocrinology 1999; 140:4732-8.

35. Latronico AC, Segaloff DL. Naturally occurring mutations of the luteinizing hormone receptor: lessons learned about reproductive physiology and $G$ protein-coupled receptors. Am J Hum Genet 1999;65:949-58.

36. Latronico AC, Anasti J, Arnhold IJP, et al. Brief Report: Testicular and ovarian resistance to luteinizing hormone caused by inactivating mutations of the luteinizing hormone-receptor gene. N Engl J Med 1996;334:507-12.

37. Stocco DM, Clark BJ. Role of the acute regulatory protein StAR in steroidogenesis. Biochem Pharmacol 1996;51:197-205.
38. Bose HS, Pescovits OH, Miller WL. Spontaneous feminization in 46,XX female patient with congenital lipoid adrenal hyperplasia due to a homozygous frameshift mutation in the steroidogenic acute regulatory protein. J Clin Endocrinol Metab 1997;82:51 1-15.

39. Tajima T, Fujieda K, Kouda N, et al. Heterozygous mutation in the cholesterol side chain cleavage enzyme (P450scc) gene in a patient with 46,XY sex reversal and adrenal insufficiency. J Clin Endocrinol Metab 2001;86:3820-5.

40. Yanase T, Simpson ER, Waterman MR. 17a-hidroxylase/17,20-lyase deficiency: from clinical investigation to molecular definition. Endocr Rev 1991;12:91-108.

41. Mendonça BB, Inacio M, Costa EMF, et al. Male pseudohermafroditism due to 5a-reductase 2 deficiency. Medicine (Baltimore) 1996;75:64-76.

42. Chamberlain NL, Driver ED, Miesfeld RL. The length and location of CAG trinucleotide repeats in the androgen receptor $\mathrm{N}$-terminal domain effect transactivation function. Nucleic Acids Res 1994;22:3181-6.

43. Adachi M, Takayanagi R, Tomura A, et al. Androgeninsensitivity syndrome as a possible coactivator disease. N Engl J Med 2000;343:856-62.

44. Hughes IA. A novel explanation of resistance to androgens. N Engl J Med 2000;343:881-2.

45. Lim HN, Chen H, McBride S, et al. Longer polyglutamine tracts in the androgen receptor are associated with moderate to severe undermasculinized genitalia in XY males. Hum Mol Genet 2000;9:829-34.

46. Zimmerman S, Steding G, Emmen JM, et al. Targeted disruption of the Insl3 gene causes bilateral cryptorchidism. Mol Endocrinol 1999;13:681-91.

47. Nef S, Parada LF. Cryptorchidism in mice mutant for Insl3. Nat Genet 1999;22:295-9.

48. Lim HN, Rajpert-De Meyts E, Skakkebaek NE, et al. Genetic analysis of the Insl3 gene in patients with maldescent of the testis. Eur J Endocrinol 2001;144:1-9.

49. Nef S, Parada LF. Hormones in male sexual development: Review. Gene \& Development 2000; 14(24): 3075-86.

50. Bernstein L, Pike MC, Depue RH, et al. Maternal hormone levels in early gestation of cryptorchid males: a case control study. Br J Cancer 1988;58:379-81.

51. Wilson JD. Androgens, androgens receptors and male gender role behavior. Horm Behav 2001;40:358-66.

\section{Endereço para correspondência:}

Sorahia Domenice

Hospital das Clínicas - FMUSP

Av. Dr. Enéas de Carvalho Aguiar 155, PAMB $2^{\circ}$. andar, bl 6 05403-900, São Paulo, SP

Fax: (01 1) 3083-0626

e.mail: sdomenice@ig.com.br 